\title{
The Effect of Various Types of Building Roof Materials on the Cooling Load
}

\author{
Raheem Kadhim Ajeel ${ }^{1}$, IR. M. Zainal Md. Yusof ${ }^{2}$ \\ ${ }^{1}$ University Tun Hussein Onn Malaysia , Batu Pahat, Malaysia 86400 Parit Raja, Batu Pahat Johor, Malaysia \\ ${ }^{2}$ Professor, University Tun Hussein Onn Malaysia , Batu Pahat, Malaysia 86400 Parit Raja, Batu Pahat Johor, Malaysia
}

\begin{abstract}
Building information modeling took great interest in recent years in the world in terms of the design simulation of the buildings and chooses the best design. Therefore, roof insulation is one of the most important strategies to reduce the electricity consumption in the building which leading cost savings and reduce the emission of gases that pollute the environment directly. This study aimed to evaluate the effect of various types of building roof materials on the cooling load. This study involved in selecting a particular building type (factory building) and the effect of the cooling load by using a various metal deck roofing with and without insulation. The cooling load requirement for the building was calculated by using Auto desk Revit software. The results indicated that roof insulation is one of the most important strategies to reduce the cooling load and enhanced the electricity consumption in the building. The twenty percent reduction in the space cooling leading cost savings and reduce the emission of gases that pollute the environment directly. The study proved that polystyrene foam better than polyurethane foam and polyethylene, where the rate to reduce the cooling loads higher by about $9 \%$ from polyurethane foam and $17 \%$ from polyethylene.
\end{abstract}

Keywords: Cooling load, Insulation strategy, Polystyrene Foam insulation, Polyurethane Foam, Polyethylene, Autodesk Revit software.

\section{Introduction}

Air-conditioning is a process that simultaneously conditions air; distributes it combined with the outdoor air to the conditioned space; and at the same time controls and maintains the required space's temperature, humidity, air movement, air cleanliness, sound level, and pressure differential within predetermined limits for the health and comfort of the occupants, for product processing, or both [1]. Air-conditioning System consists of components or equipment connected in series to control the environmental parameters. An air-conditioning system, by ASHRAE (American Society of Heating, Refrigerating and AirConditioning Engineers) definition is a system that must accomplish four objectives simultaneously. These objectives are to control, air temperature, air humidity, air circulation; and air quality. The cooling is typically done using a simple refrigeration cycle, but sometimes evaporation is used, commonly for comfort cooling in buildings and motor vehicles. In construction, a complete system of heating, ventilation and air conditioning is referred to as "HVAC". Cooling load is the rate of heat which must be removed from the space to maintain a specific space air temperature and moisture content [2]. The parameters affecting cooling load calculations are numerous, for example, the outside air temperature, the humidity ratio, the number and activity of people and etc.

These parameters are often difficult to precisely define and always intricately interrelated. Many cooling load components vary in magnitude over a wide range during a 24 hr period. These cyclic changes in load components are not often in phase with each other. Each must be analyzed to establish the maximum cooling load for a building or zone. Moreover effects of thermal accumulation also involve in calculating procedure. Therefore various models and assumptions are developed. The estimated results at the specific time of calculation are normally expected and not the exact ones [3].

Insulation of building envelopes, both opaque and transparent, is an important strategy for building energy conservation. Insulation of walls, roof, attic, basement walls and even foundations is one of the most essential features of energy efficient homes. In addition, as glass is a poor insulator, insulating transparent envelopes, windows and skylights, significantly reduces heat loss and gain during the winter and summer [4]. The insulation strategy of a building needs to be based on a careful consideration of the mode of energy transfer and the direction and intensity in which it moves. This may alter throughout the day and from season to season. It is important to choose an appropriate design, the correct combination of materials and building techniques to suit the particular situation. This study focused on reducing the electrical consumption for various environmental conditions by optimizing the cooling load of a building.

The issue in this research is that of enhancement the cooling performance by mean of using insulator. The paper is organized as follows: Section II shows the roofs effect on the cooling load. Section III indicates the requirements of insulation. Section IV describes the case study. Section V discusses the new method of simulation by using Autodesk Revit software. Section VI illustrates the simulation results and section VII summarizes the conclusion.

\section{The Roofs Effect on the Cooling Load}

In tropical countries, including Malaysia, Iraq, which is characterized by its climate heat and long-term drought during the summer season or during the year, the roof ceiling is the most important elements affecting the thermal environment inside buildings because it receives large amounts of solar radiation. For buildings in equatorial regions with warm and humid climate such as Malaysia, the roof has been said to be a major source of heat gain. Solar 


\section{International Journal of Science and Research (IJSR) \\ ISSN (Online): 2319-7064 \\ Index Copernicus Value (2013): 6.14 | Impact Factor (2014): 5.611}

protection of the roof remains one of the main concerns in the thermal design of buildings in the region [5]. Previous studies have shown that in Malaysian building, roof has a huge impact on the thermal performance of the whole building [6]. Due to its geographical location, Malaysia receives the sun directly overhead most of the day throughout the year. Therefore, major heat gain of Malaysian houses comes from the roof. According to previous studies, around $87 \%$ of heat transfer from the roof to occupant is through radiation process, whereby only around $13 \%$ of heat is transferred through conduction and convection [7], as illustrated in figure (1).

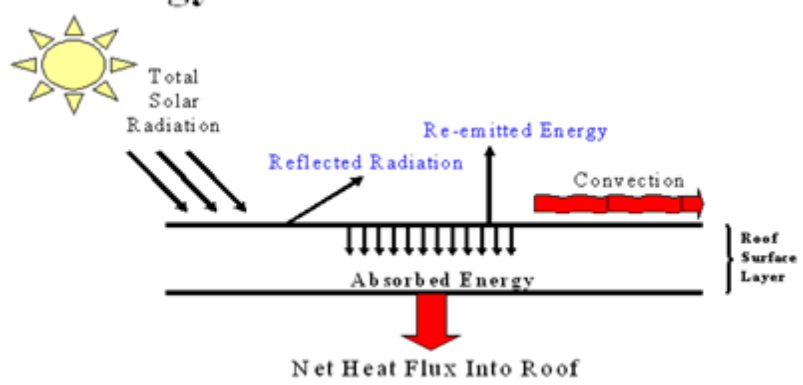

Figure 1: Energy Balance on Roof Surface

The radiant heat received by the occupants in a space can be measured as mean radiant temperature (MRT). The mean radiant temperature (MRT) is the area-weighted average of all the surface temperatures in a room, and is affected by the position of the person in relation to the various surfaces. The larger the surface area and the closer to the person, it will have more influence to an occupant's MRT. This explains why the roof plays an important role in determining the overall MRT of the building, which will have a direct impact on the thermal comfort level of the occupants. According to Peng Chen [8], the thermal radiation of roof largely depends on the composition materials.

\section{Insulation}

Insulation is one of those ubiquitous techniques that is always around, always impinging on our work, social and domestic activities and yet for most of the time is hardly noticed. Insulation is a passive product; once installed, it works efficiently, quietly and continually, usually out of sight, enclosed within a structure or a casing or under cladding.

It comes to the fore when new design of buildings, plant, equipment or production processes is being considered. It is at this stage that the right specification must be made. Any shortfall in the thickness or error in the type and application details will prove costly to rectify at a later date (Mobley, 2001).

\subsection{Generic types of insulation}

The type indicates composition (i.e. glass, plastic) and internal structure (i.e. cellular, fibrous) (Best practices guide, 2011):

1)Fibrous Insulation - composed of small diameter fibers which finely divide the air space. The fibers may be perpendicular or parallel to the surface being insulated, and they may or may not be bonded together. Silica, rock wool, slag wool and alumina silica fibers are used. The most widely used insulations of this type are glass fiber and mineral wool. Glass fiber and mineral wool products usually have their fibers bonded together with organic binders that supply the limited structural integrity of the products.

2)Cellular Insulation - composed of small individual cells separated from each other. The cellular material may be glass or foamed plastic such as polystyrene (closed cell), polyisocyanurate and elastomeric.

3)Granular Insulation - composed of small nodules which may contain voids or hollow spaces. It is not considered a true cellular material since gas can be transferred between the individual spaces. This type may be produced as a loose or pourable material, or combined with a binder and fibers or undergo a chemical reaction to make a rigid insulation. Examples of these insulations are calcium silicate, expanded vermiculite, perlite, cellulose, diatomaceous earth and expanded polystyrene. Figure 2 shows generic types of insulation.

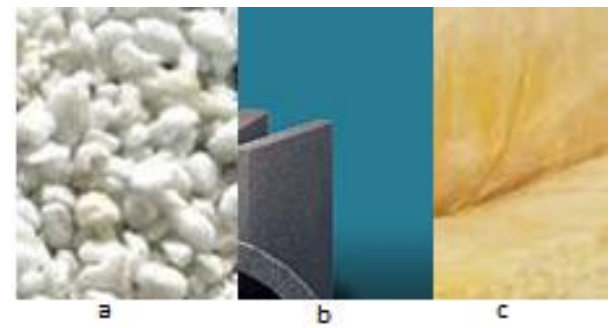

Figure 2: Granular insulation a, cellular insulation b and fibrous insulation c

\subsection{Generic forms of insulation}

Insulations are produced in a variety of forms suitable for specific functions and applications. The combined form and type of insulation determine its proper method of installation. The forms most widely used are (Best practices guide, 2011):

a) Rigid boards, blocks, sheets, and pre-formed shapes such as pipe insulation, curved segments, lagging etc. Cellular, granular, and fibrous insulations are produced in these forms.

b) Flexible blankets. Fibrous insulations are produced in flexible blankets.

c) Cements (insulating and finishing). Produced from fibrous and granular insulations and cement, they may be of the hydraulic setting or air drying type.

d) Foams. Poured or froth foam used to fill irregular areas and voids. Spray used for flat surfaces.

\subsection{Thermal Insulation}

A thermal insulation (Mobley, 2001) material is one that slows down the rate of heat loss from a hot surface and similarly reduces the rate of heat gain into a cold body. It will not stop the loss or gain of heat completely.

No matter how well insulated, buildings will need a continual input of heat to maintain desired temperature levels. The input required will be much smaller in a well-insulated 


\section{International Journal of Science and Research (IJSR) \\ ISSN (Online): 2319-7064 \\ Index Copernicus Value (2013): 6.14 | Impact Factor (2014): 5.611}

building than in uninsulated ones - but it will still be needed. The same applies to items of plant - pipes, vessels and tanks containing hot (or cold) fluids. If there is no heat input to compensate for the loss through the insulation the temperature of the fluid will fall. A wellinsulated vessel will maintain the heat of its contents for a longer period of time but it will never, on its own, keep the temperature stable. Thermal insulation does not generate heat. It is a common misconception that such insulation automatically warms the building in which it is installed. If no heat is supplied to that building it will remain cold. Any temperature rise that may occur will be the result of better utilization of internal fortuitous or incidental heat gains.

\subsection{Requirements of an insulant}

In order to perform effectively as an insulant a material must restrict heat flow by any (and preferably) all three methods of heat transfer. Most insulating materials adequately reduce conduction and convection elements by the cellular structure of the material. The radiation component is decreased by absorption into the body of the insulant and is further reduced by the application of bright foil outer facing to the product.

Mobley .R, (2001) stated that in order to reduce heat transfer by convection an insulant should have a structure of a cellular nature or with a high void content. Small cells or voids inhibit convection within them and are thus less prone to excite or agitate neighboring cells. To reduce heat transfer by conduction, an insulant should have a small ratio of solid volume to void. Additionally, a thin-wall matrix, a discontinuous matrix or a matrix of elements with minimum point contacts are all beneficial in reducing conducted heat flow. A reduction in the conduction across the voids can be achieved by the use of inert gases rather than still air. Radiation transfer is largely eliminated when an insulant is placed in close contact with a hot surface. Radiation may penetrate an open-cell material but is rapidly absorbed within the immediate matrix and the energy changed to conductive or convective heat flow. It is also inhibited by the use of bright aluminum foil, either in the form of multi-corrugated sheets or as outer facing on conventional insulants.

\section{Case Study}

Case study in this project is a simple factory building consists of two floors .Ground floor is a production space and the first floor is the factory's offices. The dimensions of the factory $\left(10 m^{*} 30 \mathrm{~m}\right)$ and has in ground floor productive machine (lathe - Dril - milling) (4 of each type). We have assumed that the factory building located in town of Batu Pahat, Johor and the latitude and longitude (1.854262835, 103.08965206). Figures 3 and 4 show the floor details of the building.

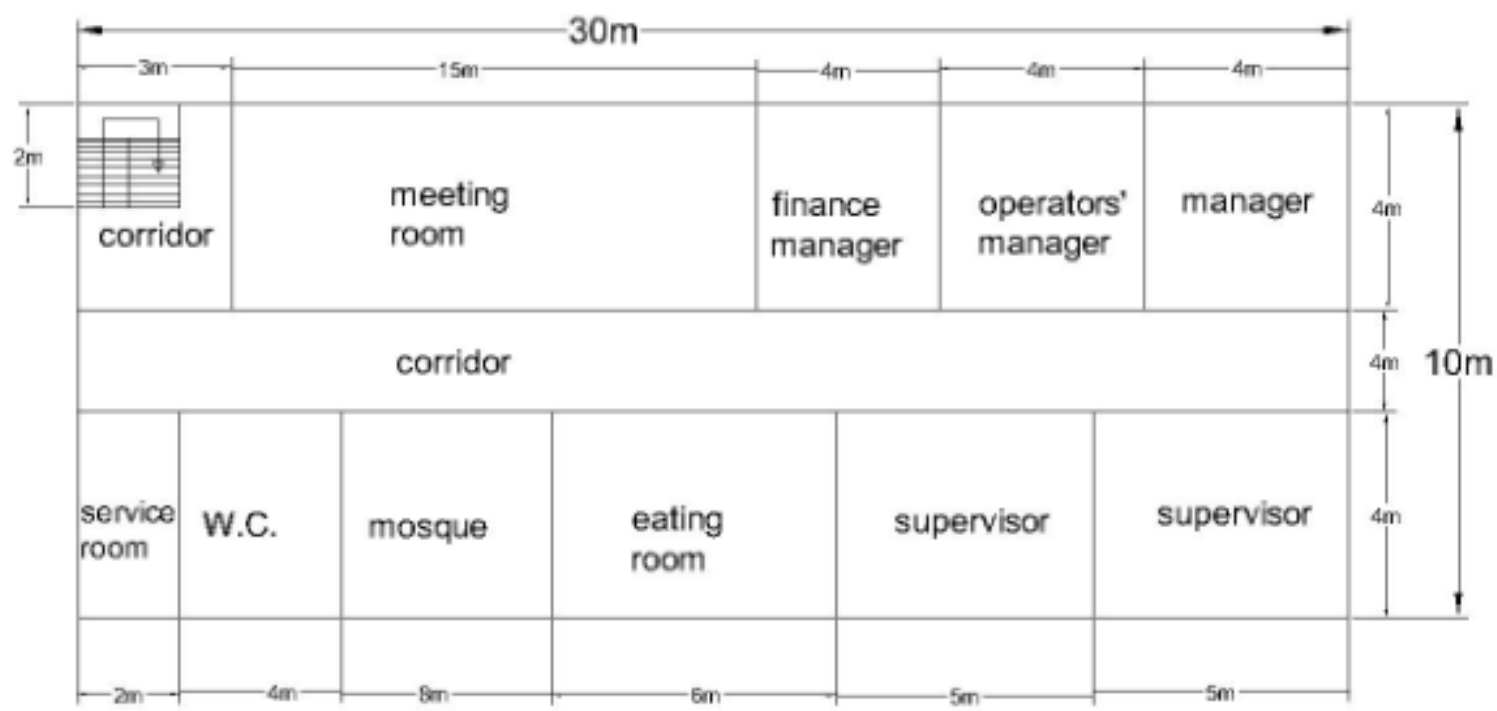

Figure 3: First floor (Administrative Area) 


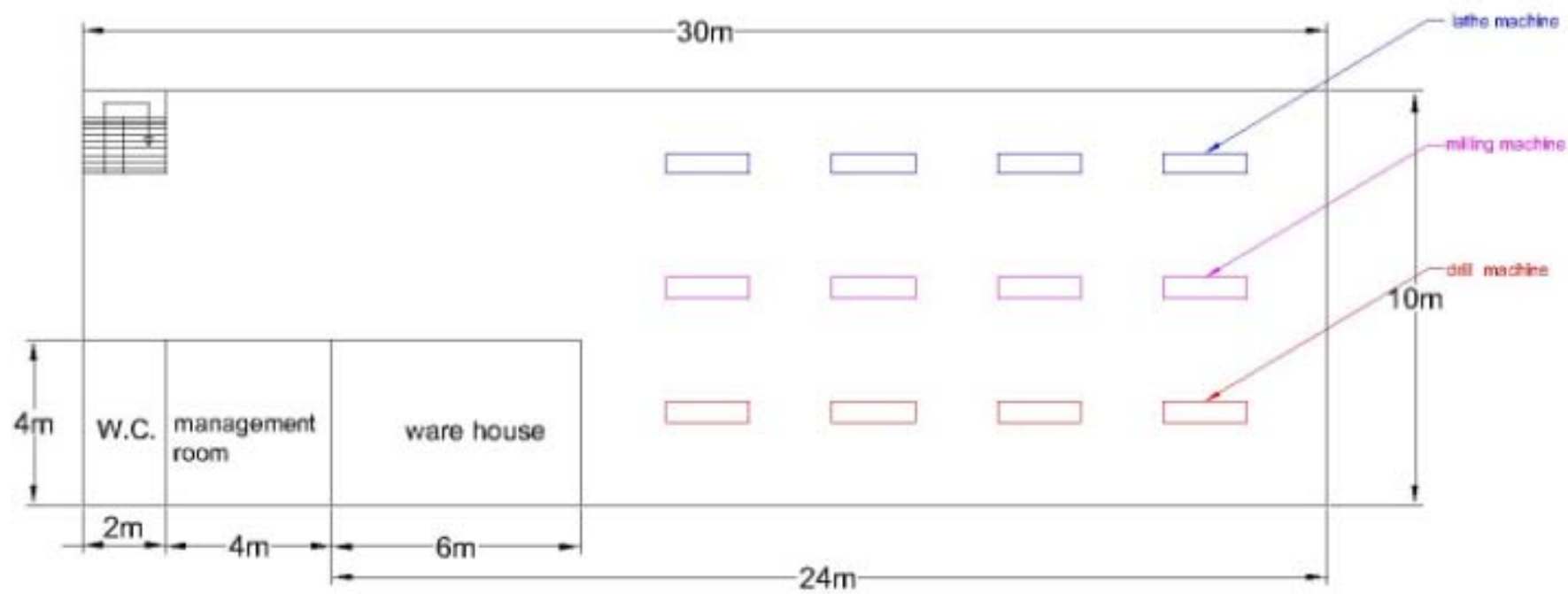

Figure 4: Ground floor (Production Area)

\subsection{Roof and wall layers}

The interior walls of the factory building consist of gibson board either the exterior walls will be from bricks. The roof layers are consisted of metal deck, insulation material which includes polystyrene foam, polyurethane foam and polyethylene (three materials at one thickness $5 \mathrm{~mm}$ ) and aluminum sheet. Figure 5 shows the roof layers.

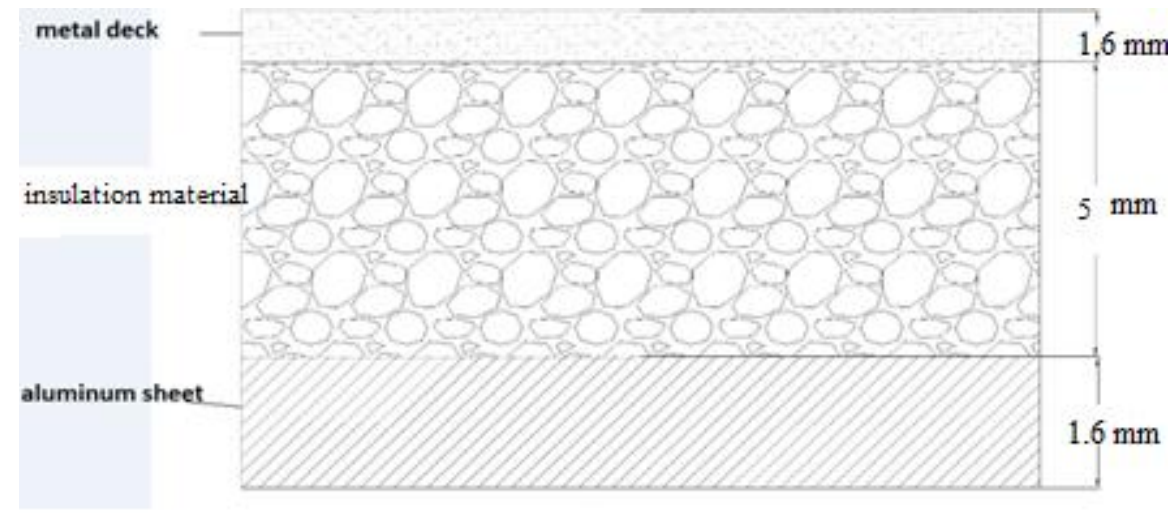

Figure 5: Roof layer with insulation material

\section{Method}

The main objective of the study is to investigate the effects of roof insulation on the cooling load of a factory building and compare the using of three material as an insulation ( polystyrene foam, polyurethane and polyethylene).The following are performed:

i. Simulate the cooling load for the model factory with metal deck roofing with and without insulation. Insulating material consisting of insulation and aluminum sheet where insulation was in same thickness but in various types (polystyrene foam, polyurethane foam and polyethylene respectively).

ii. The resulting in cooling load is compared as for part (i).The cooling load calculations are performed using Autodesk Revit software. Figure 6 shows 3D model of the factory building and the roof details without using the insulating material while figure 7 shows 3D model of the factory building by using the insulating material.

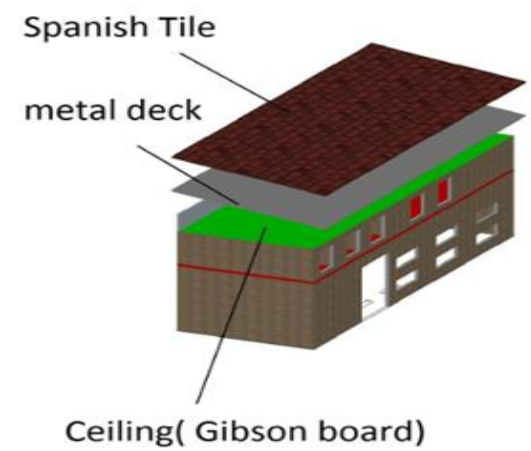

Figure 6: The roof of the factory building without the insulating material 


\section{International Journal of Science and Research (IJSR)}

ISSN (Online): 2319-7064

Index Copernicus Value (2013): 6.14 | Impact Factor (2014): 5.611

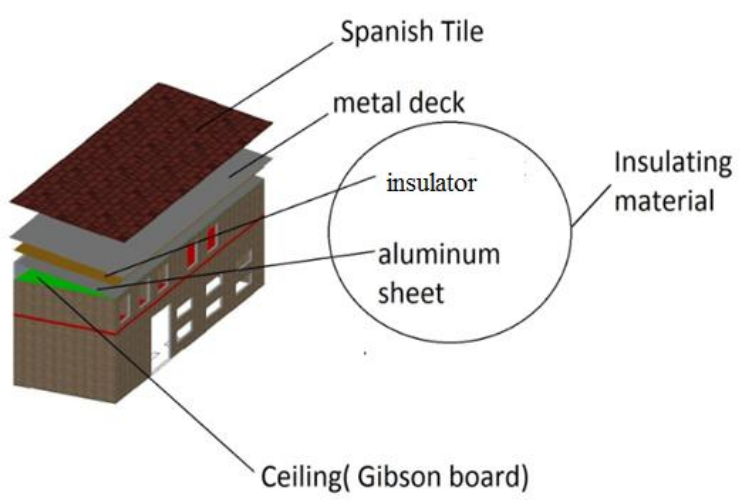

Figure 7: The roof of the factory building with insulating material

\section{Simulation}

\subsection{Building element model}

Many of settings apply to the Energy Analysis for Autodesk Revit feature to perform energy analysis using conceptual masses or building elements in this project. The energy analysis was performed by using building elements.

Energy Analysis for Autodesk Revit using building elements is intended to provide insight into potential building energy use given more detailed information typically available at later stages in the design process. Create building elements i.e. walls, roofs, floors, windows etc. (room/space elements are optional), define energy settings (especially location and building type) and submit a whole building energy simulation to the Autodesk Green Building Studio web service.

\subsection{Simulation Results}

The results of simulation were for cooling load estimation for every cases of roof with and without insulation, are presented in graphical forms. Comparisons of results between the two cases of study i.e roofing with and without insulation were carried out and on the other hand, comparisons of using the insulation material and which is better for using as an insulation.

\subsubsection{Cooling load saving}

This section presents the result and analysis of the cooling load of the factory building in both cases with and without insulation showing the effects of the outdoor design and insulation in the overall cooling load of the building. Figure 8 below presents the results of the cooling load of the factory building without insulation (A) and with using insulation; polystyrene foam (B), polyurethane foam (C) and polyethylene (D).

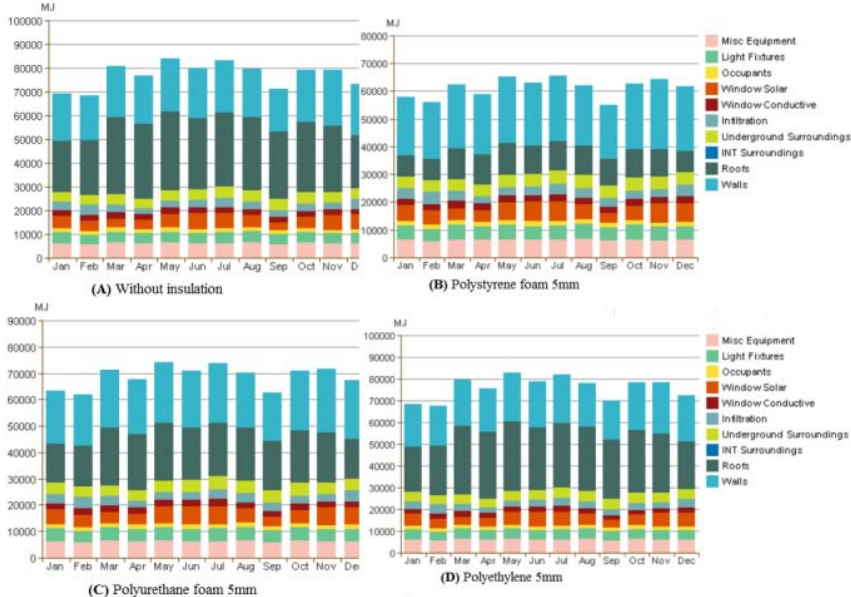

Figure 8: Building monthly cooling load for roof with and without insulation

The results indicated that the cooling load without insulation was high and ranged between 68500 and $83900 \mathrm{MJ}$, while for roof with using polystyrene ranged between 54,975 and $65,702 \mathrm{MJ}$, with using polyurethane foam ranged between 61,300 and75,350 MJ and with using polyethylene ranged between 68,870 and 82,500 MJ. Moreover, there was a difference in the cooling load from month to month. This difference is a natural result of the different temperatures and relative humidity during the year, although the difference in temperature was small, but the relative humidity has had the greatest influence in the cooling load.

\subsubsection{The effect on the cooling load - the electricity} consumption with and without insulation

This section presents the result and analysis of the cooling load on the electricity consumption with and without insulation. Figure 10 below presents the results of the electricity consumption of the factory building without insulation (A) and with using polystyrene foam (B), polyurethane foam (C) and polyethylene (D).

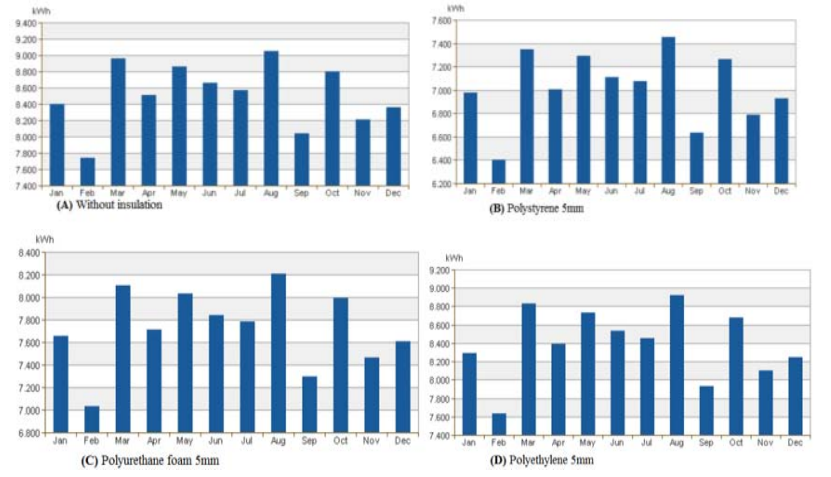

Figure 9: Monthly electricity consumption with and without insulation

The results indicated that the electricity consumption without insulation was high and ranged between 7735 - $9050 \mathrm{kWh}$, while for roof with using polystyrene foam $(5 \mathrm{~mm})$ it ranged between 6402 - $7452 \mathrm{kwh}$, with using polyurethane foam (5 $\mathrm{mm}$ ) it ranged between 7050- $8200 \mathrm{kwh}$ and 7650-8870 kwh for polyethylene. Moreover, there was a difference in the electricity consumption from month to month. This difference was a natural result of the different temperatures 


\section{International Journal of Science and Research (IJSR) \\ ISSN (Online): 2319-7064 \\ Index Copernicus Value (2013): 6.14 | Impact Factor (2014): 5.611}

and relative humidity during the year, although the difference in temperature was small, but the relative humidity has greater influence in the cooling load and thus leads to reduced electricity consumption.

\subsubsection{Monthly peak demand}

This section presents the result and analysis of the monthly peak demand for electricity with and without insulation. Figure 11 below presents the results of the monthly peak demand for electricity of the factory building with and without insulation.

The estimation of the peak demand for electricity is one of the most important features of the Autodesk Revit energy simulation. This is of great importance where the best design of the building in order to reduce the demand for electricity and knowledge of peak demand will save a lot of money and dramatically reduces the emissions of $\mathrm{CO}$ and $\mathrm{CO} 2$, which effects on the environment significantly.

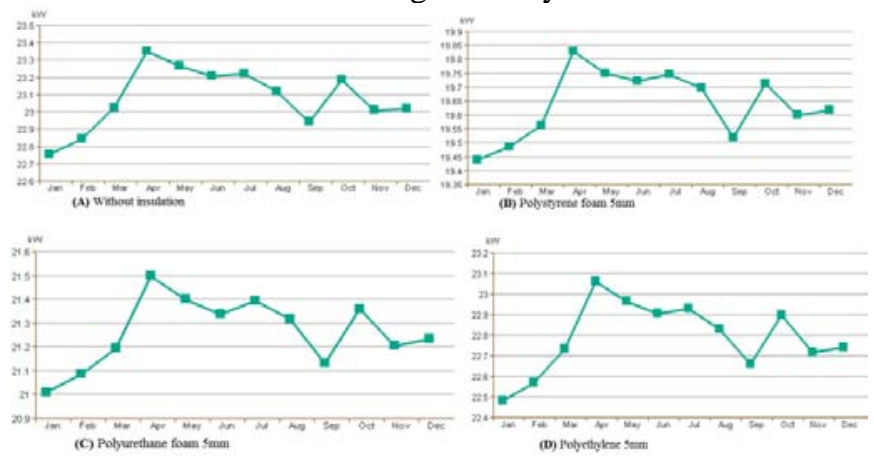

Figure 10: Monthly peak demand of electricity with and without insulation $(\mathrm{kW})$

\section{Conclusions}

For buildings in equatorial regions with warm and humid climate such as Malaysia, the roof has been said to be one of the major sources of heat gain. Solar protection of the roof remains one of the main concerns in the thermal design of buildings in the region.

The reduction in the cooling load by using insulating material in the roof is very important as a means to reduce the electrical energy consumption to cool the space and hence cost saving. Many types of material had been used as insulation with different thickness. In this paper, new software has been used to simulate the model of building to calculate the cooling load of a simulated factory building for 12 month in Batu Pahat district, Malaysia in 2013 by using Autodesk Revit software. The performance of the polystyrene foam, polyurethane foam and polyethylene were investigated and analyzed as insulations with the thickness $5 \mathrm{~mm}$ by using Autodesk Revit software. The simulation results proved useful information for roof insulation and proposed a tool i.e simulation program for estimation of the cooling load in factory building and compared the results for chose the better insulator which is polystyrene foam. On the other hand, building information modeling took great interest in recent years in the world in terms of the design simulation of the buildings and chooses the best design. Therefore, the use of software has emerged one of the most important for the simulation, this study showed that the facts about the impact of insulated roof by using the Autodesk Revit software.

\section{References}

[1] [1]. V. P. Gountis and A. G. Bakirtzis, "Bidding strategies for electricity producers in a competitive electricity marketplace," IEEE Trans. Power System, vol. 19, no. 1, pp. 356-365, Feb. 2004.

[2] [2]. J. Clerk Maxwell, "A Treatise on Electricity and Magnetism", 3rd ed., vol. 2. Oxford: Clarendon, 1892, pp.68-73.

[3] [3]. R. Benato and A. Paolucci, EHV AC Undergrounding Electrical Power. Performance and Planning. New York: Springer, 2010.

[4] [4]. Angus DC, Linde-Zwirble WT, Lidicker J et al (2001) Epidemiology of severe sepsis in the United States: analysis of incidence, outcome, and associated costs of care. Crit Care Med 29:1303-1310.

[5] [5]. Levy MM, Dellinger RP, Townsend SR, Surviving Sepsis Campaign et al (2010) The Surviving Sepsis Campaign: results of an international guideline-based performance improvement program targeting severe sepsis. Crit Care Med 38:367-374

[6] [6]. CIGRÉ Tech. Brochure \# 379, "Update of service experience of $\mathrm{HV}$ underground and submarine cable systems," 2009.

[7] [7]. E. E. Reber, R. L. Mitchell, and C. J. Carter, "Oxygen absorption in the Earth's atmosphere," Aerospace Corp., Los Angeles, CA, Tech. Rep. TR0200 (4230-46)-3, Nov. 1968.

[8] A. Bonnaccorsi, "On the Relationship between Firm Size and Export Intensity," Journal of International Business Studies, XXIII (4), pp. 605-635, 1992. (journal style)

[9] R. Caves, Multinational Enterprise and Economic Analysis, Cambridge University Press, Cambridge, 1982. (book style)

[10] M. Clerc, "The Swarm and the Queen: Towards a Deterministic and Adaptive Particle Swarm Optimization," In Proceedings of the IEEE Congress on Evolutionary Computation (CEC), pp. 1951-1957, 1999. (conference style)

[11] H.H. Crokell, "Specialization and International Competitiveness," in Managing the Multinational Subsidiary, H. Etemad and L. S, Sulude (eds.), CroomHelm, London, 1986. (book chapter style)

[12] K. Deb, S. Agrawal, A. Pratab, T. Meyarivan, “A Fast Elitist Non-dominated Sorting Genetic Algorithms for Multiobjective Optimization: NSGA II," KanGAL report 200001, Indian Institute of Technology, Kanpur, India, 2000. (technical report style)

[13] J. Geralds, "Sega Ends Production of Dreamcast," vnunet.com, para. 2, Jan. 31, 2001. [Online]. Available: http://nl1.vnunet.com/news/1116995. [Accessed: Sept. 12, 2004]. (General Internet site) 